\title{
Welfare State Development in Developing Nations: The Relationship between Organised Labour and International Organisations
}

\author{
Md. Mahmudur Rahman Bhuiyan, North South University, Bangladesh
}

\begin{abstract}
This article examines welfare state development and welfare programming in the least-developed nations using the frameworks of power resources theory and world society theory. Power resources theory emphasises the role of organised labour in social policy reforms and distributional decisions, while world society theory focuses on the role of international organisations in welfare programming in developing nations. Through a case study focusing on Bangladesh, this article examines the relative importance of labour movement and international organisations in shaping social welfare policies and programmes in developing nations. While the study finds both theories relevant and useful in the context of developing nations, it suggests that international organisations are less likely to compensate for a weak labour movement in promoting labour rights and policy reforms that are friendly to the working class in those nations.
\end{abstract}

\section{KEY WORDS}

Welfare state; labour mobilisation; international organisation; developing nations; power resources theory

\section{Introduction}

The relationship between organised labour and welfare state development is largely established in the developed capitalist nations. This is evident through the empirical robustness of power resources theory in explaining variations among welfare states in the developed democracies, which sees the development of the welfare state as a function of relative class power and suggests that a stronger labour movement leads to the development of more generous and comprehensive welfare states (Olsen and O'Connor, 1998; Olsen, 2002). However, it is not so clear whether or not this relationship holds in developing nations. World society theory brings a different explanation of welfare state development in developing nations. It suggests that international organisations such as the World Bank, the International Monetary Fund (IMF) and the International Labour Organisation (ILO) play a significant role in social policy development in the least-developed nations, leading to greater cross-national homogenisation of social policies. This article examines welfare state programming in Bangladesh using the analytical frameworks offered by both theories. It primarily addresses the question: Is the nature of social policies and programmes in developing nations better explained by the labour movement or by the involvement of international organisations? 
The article opens with a brief account of power resources theory and world society theory, and gives the rationale for the study. It then examines the roles of the labour movement and international organisations in shaping welfare programmes in Bangladesh. These sections are followed by an assessment of the premises of power resources theory and world society theory in the context of Bangladesh. The article ends with a concluding section which answers the research question.

\section{Power Resources Theory and World Society Theory}

Power resources theory (PRT) is a Marxist variant of welfare state theories. Developed by Scandinavian scholars such as Walter Korpi (1998) and Gøsta Esping-Andersen (1998), the theory focuses on the relationship between social policy and labour mobilisation. Its proponents claim that cross-national variations in welfare state development and social policy outcomes are largely a function of the relative influence of organised labour in shaping welfare policies (Esping-Andersen, 1998; Korpi, 1998; Olsen and O’Connor, 1998). Power resources are defined as attributes (capacities or means) of actors - individuals or collectives - which enable them to reward or to punish other actors.

According to power resources theorists, welfare programmes emerge in response to the "balance of power" between the capitalist class and the working class. This theory assumes that variations in the power resources between classes have significant consequences for distributive processes, levels of aspirations, institutional structures and patterns of conflict, as well as for the functioning of the state and its organs (Korpi, 1998). In countries where labour is more powerful, welfare provisions are more extensive and there are lower levels of social inequalities (Olsen, 2002).

Power resources theorists measure the strength of the working class along three dimensions: the percentage of the labour force which is unionised; the degree of centralisation and unity of the unionised labour force; and the existence of a labour or social democratic party committed to labour which has been able to achieve and maintain power for a relatively longer period of time (Olsen, 2002). The theory suggests that a high level of union membership relative to the size of the total labour force is an important indicator of labour strength. Similarly, the organisation of labour federations into central "peak" federations or confederations enables them to speak with a single voice and pose more serious challenges to capital. Moreover, if the working class has a political party (labour, social democratic or socialist) with a substantial support base, this enables them to influence the character and development of the welfare state (Olsen, 2002). In this way, power resources theory assumes that a nation-state in which the workers are highly unionised, unions are organisationally centralised, and the a party is able to hold state power for a lengthy period will have a more developed welfare state characterised by higher expenditure levels, more coverage and greater generosity.

Developed relatively recently by Meyer et al. (2008), world society theory focuses on the role of international organisations in explaining welfare state development in the developing nations. The theory assumes the presence of established global policy models as elements of the world culture which nation-states have historically tended to adopt, leading to a homogenisation of state structures and policies. It refers to international principles, conventions and policy approaches such as the Millennium Development Goals, ILO Labour Standards, the World Summit of Education for All, 
the Convention on the Elimination of All Forms of Discrimination against Women (CEDAW), Conventions on the Rights of the Child, and the Food for All world summit. World society theorists suggest that these are elements of global culture and that they play a guiding role in national policy development across the domains. This theory sees the involvement of international actors supporting developing nations because the latter lack adequate capacity to develop a "standard" social welfare system for their citizens. Developed nations and international organisations play an active role in developing nations through policy formulation, financial support, and monitoring and evaluation of policy implementation.

Examining welfare state programming in developing nations in light of power resources theory and world society theory can be interesting for four reasons. First, empirically robust in the developed world, power resources theory is hardly used in explaining social welfare policies in developing countries. Therefore, it would be interesting to see if the theory is also relevant in the developing nations. Second, the nature of the labour market in developed countries is very different from that in the developing countries. In the former, the formal economic sector is fairly large and encompasses most workers. Consequently, union density is generally high in those nations. In the developing nations, however, a large proportion of workers are involved in the informal economic sector, and they are generally not covered by labour unions. Union density rates are, therefore, very low relative to the sizes of the national labour force. As a result, labour movements often take the form of violent labour upsurge. While these mob-like labour movements often succeed in workers getting some of their demands accepted by the employers in the short term, it may be interesting to see to what extent such movements can offset the need for more unionised and centralised labour mobilisation (as emphasised by power resources theory) in promoting more sustainable labour rights and workers' well-being in developing countries. Third, in addition to domestic actors such as labour and capital, a number of foreign actors such as donor agencies and international non-governmental organisations (NGOs) play a critical role in shaping labour relations and welfare programmes in the developing nations (Gough, 2001). Given that power resources theory primarily focuses on the working class' strength in welfare programming, it may be of interest to examine if the basic premise of the theory stands in the context of more complex welfare matrices in the developing nations. Finally, world society theory apparently offers an impression that international organisations play a complementary role to labour movements in welfare policy reforms in developing nations. Therefore, it may also be interesting to see if and/or how international organisations contribute to strengthening labour welfare in developing nations.

To address the above issues, the sections below seek answers to the following questions: How critical is organised labour in promoting labour welfare in developing nations? How do international organisations engage in and shape policy decisions in developing nations? Do the activities and involvement of donor nations and international organisations compensate for unorganised labour in the developing nations?

This article addresses the above questions by deploying a case-study approach focusing on Bangladesh. It critically examines how changes in the balance of power between the working class and the capitalist class in the country have reshaped labour relations and labour rights since independence in 1971. It also sheds light on how international actors have taken control over social policy decisions and how they have influenced the development of the current Bangladesh welfare 
state. The article depends primarily on secondary data sources and consults diverse forms of published materials such as social policies of Bangladesh, books, policy papers, journal articles and reviews on social policy and programming, national development plans, newspaper reports, websites of concerned ministries and departments, and websites and publications by the country's development partners such as the World Bank, the ILO, UNICEF and UNESCO.

\section{Labour Mobilisation, Class Power and Labour Rights in Bangladesh}

Bangladesh is a South Asian developing nation which achieved independence in 1971 through a bloody liberation war against Pakistan. The nation started its welfare state with a socialist economic approach and a number of monetised and non-monetised food programmes, and has expanded social interventions over the last four decades. In 1990, total social spending was less than 1 per cent of national GDP. In 2011, the country spent about 3 per cent of GDP on social affairs (ILO, 2014). When compared to advanced welfare states, social spending at 3 per cent would represent an underdeveloped welfare state; however, in Bangladesh steady growth and expanded coverage of social contingencies and populations are signs of welfare state growth. In light of the power resources theory, this section examines how relative class power might have shaped the distributive nature of welfare policies in the country.

As stated above, power resources theorists consider union density a basic indicator of labour strength. However, in Bangladesh the national source of official statistics does not collect data on union density rates. Moreover, since a large majority of the nation's labour force (87.5 per cent) belongs to the informal sector, union density (which covers only formal-sector employees) may only partially represent the nation's labour movement (BBS, 2011). Therefore, in this study labour strength has been assessed in terms the coverage, unity and bargaining effectiveness of trade unions, and the role of the labour movement in the development of the welfare state has been assessed in terms of trade union activities and the country's labour rights. Strong trade union activities and high labour standards may indicate labour's significant contribution to the shaping of welfare provisions.

\section{Trade union activities and labour strength in Bangladesh}

The state of trade union activities has changed significantly in Bangladesh since independence. Immediately after independence, about 80 per cent of the industries in Bangladesh were publicly owned. The new state nationalised industries that were owned by Pakistanis ( 47 per cent), the East Pakistan Industrial Development Corporation (34 per cent), and foreign owners (1 per cent) (Hussain, 2005). Less than one-fifth (18 per cent) of industries owned by Bangladeshis remained private. Jute, textile and financial institutions were nationalised. Trade unions played a crucial role in running these industries in the absence of private owners and managers (Hussain, 2005). Workers in public industries enjoyed much freedom and trade union rights. Most plant-level trade unions had joined federations, particularly the Jatio Sramik League which was affiliated with the then ruling party, and new trade unions were registered. However, with the adoption of structural adjustment programmes (SAPs) backed by the IMF and the World Bank in the early 1980s, denationalisation and 
privatisation of state-owned enterprises began. ${ }^{1}$ Instead of promoting further rights and benefits, the prime concerns of industrial workers became protecting job and trade union rights in newly privatised industries (Ahmed, n.d). The demise of labour strength followed.

The subsequent history of Bangladesh saw a gradual decrease in labour strength and a shift in the balance of power in favour of the capitalist class. First-generation industrial entrepreneurship started in Bangladesh in the late 1980s, with the establishment of garment factories, which now constitute the dominant industrial subsector. Currently four million workers are employed in the garment sector; they comprise 36 per cent of the country's total industrial labour force. This subsector accounts for about 80 per cent of total exports and over 10 per cent of national GDP (Human Rights Watch, 2015). The garment sector has grown through near absolute denial of union rights. The same is true for emerging industrial sectors such as textile, pharmaceutical, food processing and ship-breaking (the dismantling of obsolete vessels for scrap).

The right of workers to association is mostly denied in the private industrial sector in Bangladesh. Until recently, there was no permission for trade union activities in the Export Processing Zones (EPZs). ${ }^{2}$ Even though trade unions are permitted outside EPZ areas, they are strongly suppressed by employers. The owners employ local gangsters to intimidate or physically assault union organisers (Human Rights Watch, 2015). Often they impose punishments, harass by filing court cases, or dismiss workers who initiate or join the trade unions (Islam and Karmaker,

\footnotetext{
${ }_{1}^{1}$ Structural adjustment programmes are policy prescriptions imposed by the IMF and the World Bank in the early 1980s upon indebted countries of the Third World. Structural adjustment was originally designed for countries of the Organisation for Economic Cooperation and Development (OECD), the most developed countries in the world, to restructure their economies. However, following the oil crisis, the emergence of huge deficits in the balance of payment in the United Sates, and the expected dismantling of the multi-fibre agreement and the European Steel price ring, the programmes were extended to developing countries (Dasgupta, 1997). Formally, the objective of SAPs was to make the economies of indebted countries more efficient and better capable of sustained growth (Bello, 1996). The programmes involve a number of tough policy conditions which include trade liberalisation, reduction of tariffs, devaluation of the local currency, privatisation of state enterprises, the elimination of pricing and wage controls, cutting subsidies in agriculture and industry, cutting social spending, deregulation of the banking system and export-oriented corporations from government controls, improving infrastructure, and creating institutions to facilitate the development of export-oriented economies (Bello, 1996; Dasgupta, 1997; Ellwood, 2002). It was supposed that these measures would slow the economy and reduce domestic demand, gradually resulting in fewer imports, along with more and cheaper exports, and in time the balance-of-payments deficit would be eliminated (Ellwood, 2002). By the late 1980s, more than seventy Third World countries had submitted to the various conditions associated with structural adjustment programmes (Bello, 1996).

2 Established to augment private and foreign direct investment, Export Processing Zones were first created in Bangladesh in 1980 under the legal framework of the Bangladesh Export Processing Zone Authority Act, 1980 (subsequently amended by Ordinance No. XLIX, 1984 and Ordinance No. LII, 1988). The Bangladesh Export Processing Zone Authority (BEPZA) established by the law is the official organ of the government to promote and regulate activities related to EPZs. Under the aegis of BEPZA, EPZs were set up in several areas of the country such as Chittagong, Dhaka, Gazipur, Comilla, Isshordi, and Mongla, where about half a million workers are employed (BEPZA, 2016). Since their inception trade union activities were prohibited in EPZ areas by the government, as it exempted EPZ enterprises from some labour-related legislation. Only in 2010, due to pressure primarily from US buyers (discussed later), the government has withdrawn those exemptions, and factory workers of EPZ areas are now permitted to form "workers welfare associations" (Islam and Asaduzzaman, 2015).
} 
2013; Islam, 2014). In some instances, factory owners blacklist workers who have joined unions. The most common technique used by factory owners to suppress union activities is to employ workers on a temporary basis, so that the right to association does not apply; management can dismiss workers at any time, thus encouraging obedience (Human Rights Watch, 2015).

Due to employer suppression, participation in trade unions is very low in Bangladesh. Trade unions have not grown as the industrial sector has expanded. For example, less than 10 per cent of garment factories in Bangladesh currently have trade unions (Human Rights Watch, 2015). Although unionisation rates in Bangladesh as a whole are unknown, none of the studies cited here estimate more than a 5 per cent union density rate. Of the total labour force in Bangladesh, 47.6 per cent are in the agricultural sector (which is dominated by self-employment and daily-based employment), 35.4 per cent are employed in the service sector, and only 17.5 per cent are employed in the industrial sector (World Bank, 2013). Again, trade union activities in the industrial sector are highly suppressed. A time series analysis based on US State Department Reports suggests that between 1981 and 2007, workers' rights in Bangladesh dropped from being "fully protected" to "somewhat restricted" and then fell to "severely restricted" after 2001 (Cingranelli-Richard, 2009). As the ILO (2012: 2) observes, "partly due to privatization and economic reforms, the trade union's role in protecting the rights of the workers has been severely impacted and has caused the decline of union membership compared to the rapid expansion of the private sector".

Trade union activities in Bangladesh are limited and fragmented. There are thirty-two registered national trade union federations, affiliated with different political parties; generally, they do not have the organisational strength or capacity to lead nation-wide movements. As seen in Tables 1 and 2, only 1902 of 7260 registered trade unions are affiliated with sectoral or national federations. This means that trade unions mainly function at the plant level. Due to financial limitations, most federations depend on financial support from political parties. As a result, the federations cannot work together to promote the interests of their members. A 2013 study suggests that only nine of thirty-four trade union federations in the garment sector are active; the study alleges that, despite repeated attempts, a number of active federations have failed to become registered, due to the influence of factory owners over public officers (Saha and Alamgir, 2014).

Table 1: Trade unions registered by the Department of Labour as of 13 January 2014

\begin{tabular}{|l|r|r|}
\hline Name of Office & $\begin{array}{r}\text { Number of trade } \\
\text { unions }\end{array}$ & $\begin{array}{r}\text { Number of union } \\
\text { members }\end{array}$ \\
\hline Department of Labour, Head Office Dhaka & 279 & 406479 \\
\hline Divisional Labour Office, Dhaka & 2924 & 695158 \\
\hline Divisional Labour Office, Chittagong & 1370 & 552469 \\
\hline Divisional Labour Office, Khulna & 1005 & 300712 \\
\hline Total & $\mathbf{7 2 6 0}$ & $\mathbf{2 3 1 9 2 5 5}$ \\
\hline
\end{tabular}

Source: ILO (2014) 
Table 2: Union federations registered by the Department of Labour as of 13 January 2014

\begin{tabular}{|l|r|r|r|}
\hline Type of Federation & $\begin{array}{r}\text { Number of } \\
\text { federations }\end{array}$ & $\begin{array}{r}\text { Number of } \\
\text { affiliated unions }\end{array}$ & $\begin{array}{r}\text { Number of } \\
\text { union members }\end{array}$ \\
\hline National federation & 32 & 1352 & 1076367 \\
\hline $\begin{array}{l}\text { Industrial federation } \\
\text { (various subsectors) }\end{array}$ & 82 & 337 & 276021 \\
\hline $\begin{array}{l}\text { Road transport federation } \\
\text { (mechanical) }\end{array}$ & 10 & 63 & 56093 \\
\hline $\begin{array}{l}\text { Road transport federation } \\
\text { (rickshaws) }\end{array}$ & 5 & 27 & 52747 \\
\hline Garment federation & 34 & 123 & 62982 \\
\hline Total & 163 & $\mathbf{1 9 0 2}$ & $\mathbf{1 5 2 5 0 1 0}$ \\
\hline
\end{tabular}

Source: ILO (2014)

Like labour federations, left-wing political groupings in Bangladesh are divided and segregated. This predates independence, since leftist political activists were divided between pro-Soviet and pro-China camps. After independence, segregation intensified due to internal factions and the resultant proliferation of leftist political parties. Currently, there are about two dozen leftist political parties in Bangladesh. Among them, only seven are active and the rest exist mainly on paper, with little visible activity. Left parties are now divided into two blocs. The first includes fourteen parties that participate in the ruling (bourgeois) alliance. The others, remaining consistent with their communist goals, formed the Democratic Left Alliance. While the Alliance has no representation in the national parliament, the former has only three seats (less than 1 per cent of the total seats) in the parliament. This signifies the extremely minor influence of leftist political parties in Bangladesh. ${ }^{3}$

Thus, in terms of all three indicators of labour strength suggested by power resources theorists - coverage of union activities, centralisation of the labour movement, and influence of left-wing political parties - the labour movement in Bangladesh is weak, and it has waned since independence. As the ILO (2012: 6) observes, "trade unions hardly exist in the country's major formal private sectors, such as garments and textiles. As a result, effective social dialogue is almost non-existent."

\section{Organisational strength and political influence of the capitalist class in Bangladesh}

While the labour movement has waned, the capitalist class has grown consistently stronger in Bangladesh. At the time of independence, when foreign owners left the country, most factories were nationalised, the few local private enterprises were small, and the capitalist class was underdeveloped and unorganised (Hashemi, 1989). As Hashemi (1989: 157) suggests, "Bangladesh lacked an indigenous capitalist class". However, with the privatisation of national factories as part of structural adjustment and the emergence of export-oriented garment industries in the 1980s, the capitalist class has presented itself as the pioneer of economic development in the country. The government offered advantages to capital to promote private entrepreneurship and attract foreign investment. It compromised labour rights by exempting EPZ enterprises from labour-related legislation. While such exemptions allowed both domestic and foreign entrepreneurs to establish more control over

${ }^{3}$ For details about leftist politics in Bangladesh see Alim (2011). 
workers, it made the workers vulnerable to the will and interest of the capitalist class.

Moreover, the capitalist class has gained significant political power (see Table 3). Historically, lawyers, professionals and intellectuals played leading roles in Bangladeshi politics (Firoj, 2013). In the early years of independence, capitalists were detached from national politics. It was only in the mid-1980s that they started to be an influential pressure group. A number of national-level trade associations, such as the Bangladesh Garment Manufacturers and Exporters Association (BGMEA), the Bangladesh Knitwear Manufacturers and Exporters Association (BKMEA), the Bangladesh Association of International Recruiting Agencies (BAIRA), and the Real Estate and Housing Association of Bangladesh (REHAB) were established around that time. However, since the early 1990s, when democracy returned after fifteen years of military rule, capitalists have been actively involved in politics. Instead of merely influencing politics from behind the scene (through patronage of particular political parties), businessmen became more interested in holding political positions and participating in policy decisions. Since the fifth parliament, elected in 1991, businessmen have consistently formed the majority in the parliament (see Table 3). The dominant presence of businessmen among the lawmakers in Bangladesh clearly indicates their increased political influence.

Table 3: Occupational backgrounds of members of parliament in Banglades

\begin{tabular}{|l|c|c|c|c|c|c|c|}
\hline \multirow{2}{*}{ Parliament } & \multicolumn{7}{|c|}{ Occupational Background (\% representation) } \\
\cline { 2 - 8 } & $\begin{array}{c}\text { Election } \\
\text { year }\end{array}$ & Businessmen & Lawyers & Professionals & Landlords & Politicians & Others \\
\hline First & 1973 & 23.7 & 26.5 & 30.7 & 2.8 & 12.7 & 3.9 \\
\hline Fifth & 1991 & 59.4 & 18.8 & 15.5 & 3.9 & 2.0 & 0.4 \\
\hline Seventh & 1996 & 47.8 & 14.4 & 8.5 & 6.9 & 3.1 & 18.9 \\
\hline Eighth & 2001 & 52.1 & 8.7 & 8.4 & 8.4 & 2.1 & 20.3 \\
\hline Ninth & 2008 & 53.5 & 13.1 & 6.4 & 7.5 & 6.1 & 13.4 \\
\hline Tenth & 2014 & 54.5 & 14.5 & 14.5 & 6.7 & 5.4 & 3.7 \\
\hline
\end{tabular}

Sources: Firoj (2013); Bangladesh Election Commission (2015).

\section{Labour rights in Bangladesh}

Labour rights are underdeveloped and hence working conditions are poor in Bangladesh. Industrial workers, particularly in the private sector, are still deprived of very basic rights such as an eight-hour working day, weekends off, minimum wage, regular payment and the right to association. A survey by the Bangladesh Institute of Development Studies (BIDS) in 1990 found that garment workers worked for twelve to eighteen hours a day, seven days a week (Paul-Majumder, 2007). Another study by BIDS in 2004 found that the daily and weekly working hours of garments workers had remained unchanged (Paul-Majumder, 2007). According to the Bangladesh Labour Force Survey of 2010, the average working week of more than half of Bangladesh's workers exceeds the legal limit; the percentage of employees working more than forty-eight hours per week has grown from 48.1 per cent in 2005 to 51.5 per cent in 2010 (Bangladesh Bureau of Statistics, 2011). As a result, most workers lose their ability to work within a few years (Paul-Majumder, 2007).

Since the formation of the first National Minimum Wage Board in 1984, the wages of garment workers have been revised only four times - in 1984, 1995, 2009 and 2013. The minimum wage grew 
from Tk. 627 in 1984 to Tk. 3000 in 2009, during a period in which the inflation rate averaged 10 per cent. In 2013, the minimum wage was set at Tk. 5300 (US\$66). Although there was resistance from the BGMEA, which wanted a much smaller increase, the government played a decisive role in fixing the minimum wage at Tk. 5300 (BDNews24, 2014). This is the lowest among the major garment exporting countries - Cambodia (US\$80), India (US\$71), Pakistan (US\$79), Sri Lanka (US\$73) and Viet Nam (US\$78) (Basher, 2013).

Moreover, factory owners often do not pay the minimum wage, or pay irregularly. According to IndustriAll Global Union, 40 per cent of factories in Bangladesh do not pay the minimum wage (BDnews24, 2014). A study by Fair Wear (a non-profit lobby group) found that some workers received less than the 2013 minimum wage and that a quarter of workers had seen their pay grade lowered (Tasin, 2013). According to the 2010 Bangladesh Labour Force Survey, casual employees receive only two-fifths of the wage of regular employees in real income. As the ILO (2013: viii) notes, "By and large, the minimum wage policy has been inadequate in terms of protecting employees, primarily because of non-compliance of employers and non-enforcement by the labour authorities".

The working-hour problem is, to some extent, related to low wages. Besides being forced to work longer hours, workers often seek additional hours to compensate for low wages. Two surveys by the Centre for Development Dialogue found that workers are often "happy" with overtime hours, since they can earn a higher overtime rate or additional income at the same regular hourly rate (Khatun et al., 2008; Rahman, Bhattacharya and Moazzam, 2008). The 2007 Wage Survey by Bangladesh Bureau of Statistics (2007) suggests that the average monthly income of wage earners was lower among those who worked sixty hours or more per week (compared to workers who worked for forty or more and fifty or more hours per week), proof that workers who work longer hours do so to compensate for low wage rates (Berik and Rodgers, 2009).

Compounding the issues of hours and wages, workplace safety and health conditions are also very poor in factories. Fires are frequent, with two out of three accidents related to faulty fire extinguishers and electrical short circuits. Between 2000 and 2013, more than 1500 workers died from industrial disasters caused by fire, building collapses or stampedes (ILO, 2013; Tasin, 2013). In 2008, the Fair Labour Association (FLA) studied three factories in Bangladesh to evaluate compliance with the workplace codes of conducts that the FLA sought to uphold in factories that supplied FLA-affiliated companies. The factories which were audited were large, employing between 963 and 1958 workers (FLA, 2008). ${ }^{4}$ Monitoring results revealed numerous violations. Of the twenty-seven violations of the FLA codes, seventeen were related to health and safety. Berik and Rodgers conclude that:

Bangladesh has a history of weak adherence to labour standards in industrial production and some of the lowest labour costs in the world. Textile and garment workers have experienced numerous violations of workers' rights supposedly guaranteed in the national labor codes, ranging from long working hours, forced and excessive overtime, illegal pay deductions, lack of safe and sanitary working conditions, and denial of the freedom to associate and bargain collectively (Berik and Rodgers, 2009: 1).

${ }^{4}$ For details of the FLA Workplace Code of Conduct see Fair Labour Association (2011). 


\section{International Organisations and the Development of the Bangladesh Welfare State}

International actors have been involved in the formulation and implementation of welfare programming in Bangladesh since independence. In fact, the welfare state began largely with food assistance programmes based on foreign aid. These international actors include foreign buyers, UN agencies, foreign donors and international non-governmental agencies.

International actors influencing social programming in Bangladesh can be categorised into two types: those which promote labour rights and those which actively participate in social policy decisions. Among those in the first group are foreign buyers and the ILO, which are most concerned with the implementation of labour rights and standards in export-oriented private sector industries, particularly garment factories. Most private sector industries in Bangladesh, particularly the garment, knitwear and shrimp-processing industries, are export-oriented. The country is the second-largest garment-exporting country in the world, and garment factories account for 79.5 per cent of Bangladesh's exports. Garments are mostly exported to the developed nations, where labour standards are very high. Currently, 60 per cent of Bangladesh's garments are exported to the European Union and 26 per cent go to the United States (Bangladesh Bank, 2014).

Given such export dependence, foreign buyers exercise significant direct and indirect influence over working conditions and workers' welfare. For example, it was primarily due to pressure from US buyers and some US trade union federations that the government of Bangladesh withdrew EPZ exemptions from legislation related to rights to association and bargaining. ${ }^{5}$ In recent years, some international buyers have applied market mechanisms to enforce ILO labour standard compliance by factories. They have included ILO labour standards in their contracts with supplying factories. They will place orders only with factories that possess certificates of compliance with the Fair Labour Association (Paul-Majumder, 2007).

In 2013, immediately after the tragic collapse of Rana Plaza which resulted in the death of 1136 garment workers, twenty-six North American brands formed the Alliance of Bangladesh Workers' Safety to promote workplace safety in Bangladeshi garment factories. The Alliance currently has 790 member factories. It regularly inspects the factories, supports them to improve health, fire and electric safety conditions, and provides certificates of international safety standards to factories which have completed all recommended renovations. Moreover, USAID has recently initiated a credit programme to improve workplace safety in Bangladeshi garment factories. The programme will provide soft loans to garment factories to renovate buildings and improve workers'

${ }^{5}$ In 1991, the American Federation of Labor and Congress of Industrial Organizations (AFL-CIO), the largest trade union federation in the United States, petitioned to revoke Bangladesh's access to tariff concessions gained through the general system of preferences (GSP) because of violations of labour rights in the EPZs. After a review of the petition, the US government decided to continue Bangladesh's GSP privileges, following the Bangladesh government's assurance that it would allow freedom of association in the EPZs by 1997 (Siddiqui, 2001). In June 1999, the AFL-CIO filed another petition to revoke the GSP privileges of Bangladesh, based on the country's failure to act in accordance with the assurance. Since then the US ambassador has repeatedly threatened withdrawal of GSP privileges on the same grounds. Exemption from the Factory Act was withdrawn in 2000. Workers of EPZ areas now can form Workers Welfare Associations under the EPZ Workers Welfare Association and Labour Relations Rights Act of 2010. 
safety (Daily Prothom-alo, 2015).

Based on international and domestic legal provisions, the ILO has secured funding from various international actors to operate a number of programmes to promote workers' right to association and collective bargaining and to improve workplace conditions. These include the Better Work Program (funded by the Governments of Canada and the Netherlands, and by the UK Department for International Development), Fundamental Rights at Work and Labour Relations (FRWLR, funded by the Government of Norway), and Developing a National Employment Injury Insurance Scheme for the Bangladesh Ready-Made Garment Sector (ILO Bangladesh, 2017). Moreover, based on a memorandum of understanding among representatives of the ILO, the Government of Bangladesh, employers and workers - known as the Sustainability Compact, launched in 2013 - the ILO now monitors the implementation of ILO labour standards in Bangladesh with the financial support of the European Union. According to the memorandum, Bangladesh is to be held responsible for the ratification and implementation of ILO conventions, formulation and implementation of labour law, trade union registration, labour inspection, formulation of policies, reporting on application of ILO conventions, and responding to ILO supervisory bodies (ILO, 2013; European Commission, 2016).

Despite the influence of foreign buyers, it is foreign donors who appear to play the most dominant role in shaping welfare provisions in Bangladesh. Even though the contribution of the foreign donors and development agencies to the national economy and the welfare system is slowly decreasing, it is still significant. The share of foreign aid is 1.8 per cent of GDP, which is almost equal to the country's total social protection spending (MoPB, 2014).

The major donors are the United Kingdom, Japan, USAID, the European Union, Canada, Sweden, Norway, Australia, the Netherlands, Denmark, various UN agencies, the Asian Development Bank and the World Bank Group (International Development Association). These donors provide aid and assistance in a coherent way. In addition, the Paris Consortium was established in 1974 to coordinate donor countries. It was replaced by the Bangladesh Development Forum (BDF) in 2005. Members of the BDF are Australia, Belgium, Canada, Denmark, France, Finland, Germany, Italy, Japan, the Netherlands, Norway, Sweden, Switzerland, the United Kingdom, the United States, the Asian Development Bank, the European Union, the International Development Association, the International Fund for Agriculture and Development, and various UN Agencies including the United Nations Development Programme (UNDP). Saudi Arabia and Kuwait participate in the Forum meetings as observers.

Members of the BDF review and coordinate donor policies at an annual meeting held in Bangladesh. Bangladesh prepares a Country Economic Memorandum for the meeting which addresses both macroeconomic and microeconomic performance and assesses the need for external aid for the following fiscal year.

There is also a Local Consultation Group (LCG) of the donors. The LCG was formed in 1974 under the direction of the World Bank, which maintained leadership until 2005. Since then, leadership rotates among donor countries. The LCG has twenty-four sector-specific groups including agriculture, fisheries, water management, environment, power, rural infrastructure, railways, urban sector, water supply and sanitation, education, health and population, NGOs, poverty issues, good governance, food aid, technical assistance to coordination, micro finance, private sector 
development, and women and gender equality. Various donors are responsible for the sub-group activities. The sub-groups meet frequently, sometimes once a month, to identify potential areas of policy and programme development (Sørvald et. al., 2005; Islam, 2016).

Foreign donors exercise influence in shaping social welfare provisions in Bangladesh in three ways: first, through project-based financing; second, by controlling policy and programme frameworks in the name of technical support; and third, via monitoring the implementation of programmes funded fully or partially by donors. Foreign donors often introduce projects in certain policy areas in partnership with the government or local NGOs. They do so as a means to highlight a problem area which is yet to gain national attention. Later, they influence the government to incorporate these pilot projects as sectoral programmes. For example, from 2002 to 2008 the World Food Programme piloted the School Feeding Programme (which provides nutrient-rich meals to elementary students to promote school enrolment and child nutrition). In 2009, school feeding was adopted as a national programme for primary school children, based on the World Food Programme model. Similarly, the Reaching Out-of-School Children (ROSC) Programme was introduced in 2004 as a non-formal-education project by the World Bank to cover children who did not go to elementary school. The World Bank provided funding and technical support for the project, and NGOs as implementation partners operated it, while the Ministry of Primary and Mass Education administered the project. Once the ROSC project was closed in 2013, the programme and The Second Chance and Alternative Education (SCAE) Programme (developed following the ROSC model) were adopted by the government in the ongoing Primary Education Development Programme-III) (MoPMEB, 2011, 2014). ${ }^{6}$

In recent years, development partners have promoted a sector-wide programming (SWP) approach in Bangladesh. So far, health and food policy domains have been brought under SWP. Since 1998, the World Bank has dominated a consortium of multilateral and bilateral donors in sector-wide reforms such as the Health and Population Sector Programme 1998-2003 and the Heath, Nutrition and Population Sector Programme 2005-2010. The Bangladesh Development Forum contributes about 27.5 per cent of the total cost of the ongoing Health, Population, Nutrition Sector Development Programme (HPNSDP) (MoHFWB, 2011). ${ }^{7}$ Similarly, the National Food Policy Plan of Action 2008-2015 was the brainchild of concerned staff of the Food and Agriculture Organization (FAO), who contributed to the formulation of the Plan of Action through policy review and drafting. The Bangladesh Country Investment Plan (CIP) 2011 for agriculture, food and nutrition was also developed through technical and methodological support from the FAO and the

${ }^{6}$ PEDP-III is the third in a series of large investments in the primary education sector in Bangladesh since 2000. While PEDP-I and PEDP-II consisted of several projects financed and managed separately by development partners, PEDP-III is a sector-wide programme covering the entire range of pre-primary and primary education systems in Bangladesh. About 17 per cent of the project's total budget (US $\$ 8.3$ billion) is contributed by the development partners (MoPMEB, 2011, 2014).

${ }^{7}$ HPNSDP is the third sector-wide programme in the health sector, and is one of the world's largest healthsector programmes. It covers the entire population of Bangladesh in seven areas of intervention: (a) maternal, neo-natal, child, reproductive and adolescent health; (b) population and family planning services; (c) nutrition and food safety; (d) communicable and non-communicable diseases; (e) climate change and health protection; (f) alternative medical care; (g) behavioural change communication-related programmes (MoHFWB, 2011). 
International Food Policy Research Institute (IFPRI), as well as financial support from USAID. About one-third of the cost of the CIP is financed by development partners. Both the SWP in the health domain and the Plan of Action and CIP in the food domain include monitoring and evaluation components (Food Planning and Monitoring Unit, 2008, 2013; MoHFWB, 2011).

However, there is a pattern in the activities of foreign donors in welfare programming in Bangladesh. Their involvement across the social policy domains is not uniform. A review of the welfare matrix of the Bangladesh welfare system by Bhuiyan (2015) suggests that welfare state programmes are more comprehensive and generous in food, education and health policy areas where the foreign donors are more engaged. Conversely, care for the elderly, children and persons with disabilities, and the housing and labour market policy domains are largely underdeveloped, reflecting minimalist welfare programming practices. Many standard programmes targeting the working class that feature the welfare states in developed democracies - such as pension schemes elderly care, care for persons with disabilities, childcare, subsidised housing, rent control provisions, compensation for workplace injuries, and employment insurance are largely absent in Bangladesh. Foreign donors' involvement in these policy areas is also very weak.

\section{Do International Organisations Make Organised Labour Irrelevant?}

Do the observations that both power resources theory and world society theory are relevant in the context of Bangladesh mean that labour mobilisation and international organisations play complementary roles in welfare programming in developing nations? Does the involvement of foreign donors in policy decisions in nations like Bangladesh compensate for weak labour structures? One may see the involvement of international actors in social programming in developing nations through a normative lens and argue that the dominant presence of international actors reinforces the labour movement, which explains the steady growth of welfare states. However, the pattern that is found in the activities of international actors in social policy development and programming in Bangladesh indicates that this may not be the case. The emphasis of dominant global organisations such as the UN agencies, the World Bank and the IMF on programming in education, health and food, and their relative reluctance to engage on certain other issues, as outlined above, suggest that the agenda of those actors differs from what the working class in capitalist economies fight for.

Theoretically related to the power resources theory, the structural-Marxist perspective may better explain the motives of dominant foreign actors in social welfare programming in developing nations. This perspective holds that social programmes are introduced because they are necessary for the capitalist system. Structural-Marxists divide social expenditure into three types: social investment, social consumption and social expenses. Social investment refers to services and projects that raise labour productivity, such as education and labour market training. Social consumption refers to services and projects that lower the costs of reproducing labour power, such as healthcare and childcare; they are indirectly productive for capitalists in that they contribute to economic growth in the private sector. Finally, the notion of social expenses refers to services and projects that maintain social stability and promote social harmony, such as social assistance and social insurance; they provide an environment where production and capital accumulation can proceed without hindrance. These benefits are closely monitored and restricted. According to structural-Marxist theorists, social 
investment and social consumption expenditures of the state correspond to its capital accumulation function, while social expenses correspond to legitimation. Both functions are translated into all state policy, including social policies (Djao, 1992).

In light of the structural-Marxist perspective, it can be argued that the foreign actors involve themselves in social programming in developing nations because they need to. In a context where global capital relies on labour located in the developing world for production, foreign actors' greater involvement in education, food and health can be seen as a reflection of their programming priorities in social investment and social consumption. Given that the labour movement is weak and the working class is less capable of hindering the production and capital accumulation processes, social expenses are still a low priority. The involvement of foreign donors and international development agencies in social programming is, therefore, not an alternative to a strong labour movement in developing nations in promoting labour rights and labour-friendly legislation.

One may think that foreign donors have greater control over policy decisions in developing nations due to the latter's dependence on foreign aid. However, in the case of Bangladesh, although the nation's dependence on foreign assistance has decreased significantly, foreign donors' influence on policy decisions has remained largely intact. ${ }^{8}$ It may be more reasonable to argue that a weak labour movement leaves room for international bodies to step in and shape the welfare state of developing nations. The historical role of influential international bodies such as the World Bank and the IMF in developing nations must support this claim. These institutions emerged as the collectors of petrodollars on behalf of the developed nations in the 1980s and imposed austerity measures on developing nations in the form of structural adjustment programmes to enable these nations to service foreign debts. As a result, labour movements in the developing countries collapsed and the states lost the capacity to support their citizens and protect their labour forces (Schmidt, 1999). These developments offered easy access for foreign donors to promote social investment and social consumption programming in developing countries in favour of global capital.

The privilege that international bodies exercise in the developing nations is thus the result of a process. The absence of a strong labour movement allows the dominant international actors to prioritise and implement programmes in which they are interested (often in collaboration with the nation-state and/or NGOs). The local capitalist class may allow the international actors to deliver some welfare provisions as this serves their interests and helps them to avoid their social responsibilities. As a result, there are programmes that are largely disconnected from the needs of the working class. In other words, the involvement of international actors does not compensate for the weakness of the labour movement in developing nations.

The dominant role of foreign donors in shaping programmes also represents a function of the balance of power, where the dominant nations and institutions promoting the interests of international capital step in to implement their agenda in the absence of pressure from below, such as from the labour movement. Thus, the undeveloped labour rights and the welfare state of Bangladesh can be seen as a result of inadequate capacity of the working class to mobilise power

8 In the 1980s, 60-90 per cent of Bangladesh's development budgets were based on foreign assistance, which constituted 15-20 per cent of its GDP. Now foreign aid constitutes less than 2 per cent of GDP (World Bank, 2013). 
resources on their own behalf. International organisations thus do not seem to make organised labour irrelevant in welfare state development in developing nations.

\section{Conclusion}

In Bangladesh, the labour movement has gradually declined since independence. Current union membership is very low, and trade union activities are fragmented and largely limited to the plant. Moreover, trade union federations are weak, incapable of leading nation-wide labour movements. The left-wing parties on which unions depend have little electoral power and few resources. Working conditions and labour rights are very poor, and factory workers are deprived of basic rights to minimum wages and collective bargaining. Bangladesh has yet to introduce simple provisions such as disability pensions and old age pensions for workers in the private sector - legislation and benefits that were introduced in developed nations when they were industrialising.

Thus, the working class in Bangladesh has become weaker since independence while the capitalist class has become stronger. As a result, the balance of power between the classes favours the capitalist class. This helps to explain the poor working conditions and labour rights in Bangladesh. Since the power resources theory assumes that high labour mobilisation leads to more comprehensive, generous and supportive welfare provisions, it can be reasonably claimed that the state of labour rights and provisions in Bangladesh is poor and underdeveloped because labour and left movements in the country are weak and fragmented.

We have also observed the involvement of many international actors in social policy and programming decisions in Bangladesh. Among them, foreign buyers and the ILO are mostly concerned with enforcing labour standards and rights in export-oriented private industries. Other actors, such as donor nations and agencies, are involved in policy formulation, planning and programming across different social policy areas, especially in food, education and health. With such active presence of international actors in social welfare programming, we find support for the world society theory in the context of Bangladesh, a representative case for developing nations in this examination.

The power resources theory and world society theory allow us to see the development of welfare states in developing nations through two different lenses. While the former emphasises the role of the labour movement (pressures from below), the latter focuses on the role of international

actors (pressure from the supra-national level). Both theories seem to be relevant in understanding welfare state development in developing nations, and one does not rule out the other. While international organisations and foreign donors seem to play an important role in shaping social policies and programmes in developing nations, they do not offset the necessity of organised labour for promoting labour-friendly legislation and social welfare provisions. Considering the observed relevance of power resources theory in the contexts of both developed and developing nations, one may reasonably ask: is organised labour a universal necessity to promote better living standards and the well-being of working and low-income people? The answer is probably "yes". Further studies in other developing country contexts may provide a more reliable answer to this question. 


\section{REFERENCES}

Ahmed, M. (n.d) Trade Union in Bangladesh: Issues, Agenda and Legislation. Available online at http://jatiyosramikjote.org/tubook.pdf [accessed 21 August 2017].

Alim, S.F. (2011) Left Movement in Post-Independence Era. The Daily Star, March 17. Available online at http://archive.thedailystar.net/suppliments/2011/anniversary/section2/pg11.htm [accessed 21 August 2017].

Bangladesh Bank (2014) Annual Report 2012-13. Available online at http://www.bangladeshbank.org/openpdf.php [accessed 21 August 2017].

Bangladesh Bureau of Statistics (BSS) (2007) Key Indicators from the Wage Survey 2007. Available online at http://www.bbs.gov.bd/dataindex/key_wage07.pdf [accessed 21 August 2017].

Bangladesh Bureau of Statistics (BBS) (2011) Report on Labour Force Survey 2010. Dhaka: Statistics Division, Ministry of Planning, Government of the Peoples' Republic of Bangladesh.

Bangladesh Election Commission (2015) Candidate Disclosure, 10 $0^{\text {th }}$ General Election. Available online at http://www.ec.org.bd/English/index.php [accessed 21 August 2017].

Bangladesh Export Processing Zone Authority (BEPZA) (2016) Annual Report 2015-2016. Available online at http:/ /www.bepza.gov.bd/reports [accessed 21 August 2017].

Basher, A. (2013) Minimum Wage in RMG Sector from Global Perspective. The Daily Financial Express, November 25.

Bhuiyan, M.M.R. (2015) Understanding and Explaining Social Welfare Policies in Developing Nations. Unpublished $\mathrm{PhD}$ thesis, University of Manitoba, Winnipeg, Canada.

BDnews24. (2014) 40\% Factories Don't Pay Minimum Wage. Bdnews24, February 22. Available online athttp://bdnews24.com/economy/2014/02/22/40-factories-dont-pay-minimum-wage [accessed 21 August 2017].

Bello, W. (1996) Structural Adjustment Programs - Success for Whom? In The Case against the Global Economy, edited by J. Mander and E. Goldsmith. San Francisco: Sierra Club Books.

Berik, G., and Y.v.d. M. Rodgers (2009) Bangladesh's Ready-Made Garments Sector: Exports, Employment, and Working conditions. Journal of Bangladesh Studies, 11(2): 1-19.

Cingranelli, D.L. and D.L. Richards (2009) CIRI Human Rights Dataset. Available online at http://www.nsd.uib.no/macrodataguide/set.htmliid=3\&sub=1 [accessed 21 August 2017].

Daily Prothom-alo (2015) Six Factories Received International Recognition. The Daily Prothom-alo, September 3. Available online at http://www.prothom-alo.com/economy/article/621262 [accessed 22 August 2017].

Dasgupta, B. (1997) SAP: Issues and Conditionalities. Economic and Political Weekly - A Global Review, 32(2021): 1091-1104.

Djao, A. (1992) The State and Social Welfare. In Debates in Canadian Society, edited by R. Hinch. Scarborough: Nelson.

Ellwood, W. (2002) Debt and Structural Adjustment. In The No-Nonsense Guide to Globalization, edited by W. Ellwood. Toronto: Between the Lines.

Esping-Andersen, G. (1998) Three Political Economies of the Welfare State. In Power Resources Theory and the Welfare State: A Critical Approach, edited by J.S. O'Connor and G.M. Olsen. Toronto: University of Toronto Press.

European Commission (2016) Bangladesh Sustainability Compact: Technical Status Report. Available at http://trade.ec.europa.eu/doclib/docs/2016/august/tradoc_154841.pdf [accessed 21 August 2017]. 
Fair Labor Association (FLA) (2008) 2008 Tracking Charts. Available online at http:/ / fairlabor.org/trackingcharts.php?y=2008 [accessed 21 August 2017].

Fair Labor Association (FLA) (2011) FLA Workplace Code of Conduct and Compliance Benchmarks. Available online at http://fairlabor.org/sites/default/files/fla_complete_code_and_benchmarks.pdf [accessed 21 August 2017].

Firoj, J. (2013) Forty Years of Bangladesh Parliament: Trends, Achievement and Challenges. Journal of the Asiatic Society of Bangladesh, 58(1): 83-128.

Food Planning and Monitoring Unit (2008) National Food Policy Plan of Action (2008-2015). Dhaka: Ministry of Food. Available online at https://www.gafspfund.org/sites/gafspfund.org/files/Documents/ NationalFoodPolicyPlanofActionFINAL.pdf [accessed 21 August 2017].

Food Planning and Monitoring Unit (2013) National Food Policy Plan of Action and Country Investment Plan Monitoring Report 2013. Dhaka: Ministry of Food. Available online at http://fpmu.gov.bd/agridrupal/sites/default/files/file/MR-2013/Monitoring\%20Report-2013.pdf [accessed 21 August 2017].

Gough, I. (2001) Globalization and Regional Welfare Regimes: The East Asian Case. Global Social Policy. 2(1): 163-189.

Hashemi, S.M. (1989) Bangladesh: Aid Dependence and the Structure of Poverty. In The Challenge in South Asia: Development, Democracy and Regional Cooperation, edited by P. Wignaraja and A. Hossain. New Delhi: Sage.

Human Rights Watch (2015) Whoever Raises their Head Suffers the Most: Workers' Rights in Bangladesh Garment Factories. Available online at https://www.hrw.org/report/2015/04/22/whoever-raises-their-headsuffers-most/workers-rights-bangladeshs-garment [accessed 21 August 2017].

Hussain, A. (2005) Bangladesher Shromik. Anduloner Etihad (in Bengali). Dhaka: Porua.

International Labour Organisation (ILO) (2012) Decent Work Country Profile Bangladesh. Available online at www.ilo.org/wcmsp5/groups/public/---dgreports/-integration/documents/publication/wcms_216901. pdf [accessed 21 August 2017].

International Labour Organisation (ILO) (2013) Decision on the 13th Item on the Agenda: Reports of the Officers of the Governing Body. Available online at http://www.ilo.org/gb/decisions/GB317decision/ WCMS_208618/lang--en/index.htm [accessed 21 August 2017].

International Labour Organization (ILO) (2014) The Third Supplementary Report to the Director General: Situations of Trade Union Rights in Bangladesh. Available online at http://www.ilo.org/wcmsp5/groups/public/--ed_norm/---relconf/documents/meetingdocument/wcms_235773.pdf [accessed 21 August 2017].

International Labour Organization (ILO) Bangladesh (2017) ILO Country Office for Bangladesh Newsletter 7. July. Available online at http://www.ilo.org/dhaka/Whatwedo/Publications/WCMS_566884/lang-en/index.htm [accessed 21 August 2017].

Islam, R. (2014) Pushak karkhana Nie Markin Protibedon: Union Korte Malikder Badha (in Bengali). The Daily Prothom-alo. , February 12.

Islam, M.R. (2016) NGOs, Social Capital and Community Empowerment in Bangladesh. Singapore: Palgrave Macmillan.

Islam, F. and M. Asaduzzaman (2015) Legal Framework for Trade Unionism in Bangladesh. IOSR Journal of Humanities and Social Sciences, 20(11): 13-19.

Islam, R. and S. Karmaker (2013) Poshak Shilper Shromikder Nana Hoyrani: Trade Unione Badha Dichhen Malikera (in Bengali). The Daily Prothom-alo, December 26. Available online at http://www.prothomalo.com/economy/article/108172 [accessed 22 August 2017]. 
Khatun, F., D Bhattacharya, M. Rahman, and K.G. Moazzem (2008) Gender and Trade Liberalization in Bangladesh: The Case of the Ready-Made Garments. Dhaka: Centre for Policy Dialogue.

Korpi, W. (1998) Power Resources Approach vs Action and Conflict: Intentional Explanation in the Study of Power. In Power Resources Theory and the Welfare State: A Critical Approach, edited by J.S. O'Connor and G.M. Olsen. Toronto: University of Toronto Press.

Meyer, J.W., J. Boli, G.M. Thomas and F.O. Ramirez (2008) World Society and the Nation-State. In The Globalization Reader, edited by F.J. Lechner and J. Boli. Oxford: Blackwell.

Ministry of Health and Family Welfare, Bangladesh (MoHFWB) (2011) Strategic Plan for Health, Population and Nutrition Sector Development Program (HPNSDP) 2011-2016. Dhaka: Ministry of Health and Family Welfare.

Ministry of Planning, Bangladesh (MoPB) (2014) National Social Protection Strategy (NSPS). Available online at http://www.plancomm.gov.bd//upload/2014/NSPS.pdf [accessed 22 August 2017].

Ministry of Primary and Mass Education, Bangladesh (MoPMEB) (2011) Main Document: Third Primary Education Development Program (PEDP3). Dhaka: Directorate of Primary Education.

Ministry of Primary and Mass Education, Bangladesh (MoPMEB) (2014) Harmonized Social Management Framework. Dhaka: Directorate of Primary Education.

Olsen G.M. (2002) The Politics of the Welfare State: Canada, Sweden and the United States. Toronto: Oxford University Press.

Olsen, G.M. and J.S. O'Connor (1998) Introduction - Understanding the Welfare State: Power Resources Theory and its Critics. In Power Resources Theory and the Welfare State: A Critical Approach, edited by J.S. O'Connor and G.M. Olsen. Toronto: Toronto University Press.

Paul-Majumder, P. (2007) Banghladesher Pushak Shilpo Khetre Shrom Odhikarer Obosta Ebong Shromik Oshotuser Sorup (in Bengali). Bangladesh Development Studies, 24(1): 1-25.

Rahman, M., D. Bhattacharya and K.G. Moazzam (2008) Bangladesh's Apparel Sector in Post-MFA Period: A Benchmarking Study on the ongoing Restructuring Process. Dhaka: Centre for Policy Dialogue.

Saha, M. and M. Alamgir (2014) Trade Union in RMG Sector: Most Federations Inactive, Active Ones Denied Registration. New Age, August 5. Available online at http://newagebd.net/37261/most-federationsinactive-active-ones-denied-registration/\#sthash.IPflEbS1.dpbs [accessed 22 August 2017].

Schmidt, V.A. (1999) The Changing Dynamics of State-Society Relations in the Fifth Republic. West European Politics, 22: 141-165.

Siddiqui, A. (2001) Bangladesh: Human Rights in Export Processing Zones. Asian Labour Update, 38. Available online at http://old.amrc.org.hk/content/bangladesh-human-rights-export-processing-zones [accessed 22 August 2017].

Sørvald, M., Nordic Consulting Group Norway and S.M.N Alam (2005) Evaluation of the "Strategy for Women and Gender Equality in Development Cooperation (1997-2005)". Country Case Study: Bangladesh. Available online at http://www.norad.no/globalassets/import-2162015-80434am/www.norad.no-ny/filarkiv/vedlegg-til-publikasjoner/country-case-study---bangladesh.pdf [accessed 22 August 2017].

Tasin, F. (2013) The Garment Sector: Strength, Prospects and Challenges. The Daily Star, May 21. Available online at http://archive.thedailystar.net/beta2/news/the-garment-sector-strength-prospects-andchallenges [accessed 22 August 2017].

World Bank (2013) World Development Indicators Online Database. Washington, DC: World Bank. 


\section{BIOGRAPHICAL NOTE}

Md. Mahmudur Rahman Bhuiyan is Assistant Professor of Political Science and Sociology at North South University, Bangladesh. He teaches introductory political science and sociology, social research methods, comparative welfare states and political sociology. His research primarily examines the nature and trends of welfare state development in developing nations. He has published in journals such as the Journal of Health, Politics, Policy and Law, the Social Science Review and Canadian Ethnic Studies. [Email: bhuiyan75@gmail.com] 